\title{
AUTOTROPHIC AMMONIA REMOVAL FROM LANDFILL LEACHATE USING ANAEROBIC MEMBRANE BIOREACTOR
}

\author{
S. Suneethi \\ Kurian Joseph \\ Centre for Environmental Studies, Anna University, Chennai, \\ India
}

\begin{abstract}
Anaerobic Membrane Bioreactor (AnMBR) is an innovative high cell density system having complete biomass retention, high reactor loading and low sludge production and suitable for developing slow growing autotrophic bacterial cultures such as ANAMMOX. The Anaerobic Ammonium Oxidation (ANAMMOX) process is an advanced biological nitrogen removal removes ammonia using nitrite as the electron acceptor without oxygen. $\mathrm{The} \mathrm{NH}_{4}{ }^{+}-\mathrm{N}$ in the landfill leachate that is formed due to the release of nitrogen from municipal solid waste (MSW), when discharged untreated, into the surface water can result in eutrophication, aquatic toxicity and emissions of nitrous oxide $\left(\mathrm{N}_{2} \mathrm{O}\right)$ to atmosphere. Besides, $\mathrm{NH}_{4}{ }^{+}-\mathrm{N}$ accumulation in landfills poses long term pollution issue with significant interference during post closure thereby requiring its removal prior to ultimate disposal into inland surface waters. The main objective of this study was to investigate the feasibility and treatment efficiency of treating landfill leachate (to check) for removing $\mathrm{NH}_{4}{ }^{+}-\mathrm{N}$ by adopting ANAMMOX process in AnMBR. The AnMBR was optimized for Nitrogen Loading Rate (NLR) varying from 0.025 to $5 \mathrm{~kg} \mathrm{NH}_{4}{ }^{+}-\mathrm{N} / \mathrm{m}^{3} / \mathrm{d}$ with hydraulic retention time (HRT) ranging from 1 to $3 \mathrm{~d}$. $\mathrm{NH}_{4}{ }^{+}-\mathrm{N}$ removal efficacy of $85.13 \pm 9.67 \%$ with the mean nitrogen removal rate (NRR) of $5.54 \pm 0.63 \mathrm{~kg} \mathrm{NH}_{4}{ }^{+}-\mathrm{N} / \mathrm{m}^{3} / \mathrm{d}$ was achieved with nitrogen loading rate (NLR) of $6.51 \pm 0.20$ $\mathrm{kg} \mathrm{NH}_{4}{ }^{+}-\mathrm{N} / \mathrm{m}^{3} / \mathrm{d}$ at $1.5 \mathrm{~d}$ HRT. The nitrogen transformation intermediates in the form of hydrazine $\left(\mathrm{N}_{2} \mathrm{H}_{4}\right)$ and hydroxylamine $\left(\mathrm{NH}_{2} \mathrm{OH}\right)$ were $0.008 \pm 0.005 \mathrm{mg} / \mathrm{L}$ and $0.006 \pm 0.001$ $\mathrm{mg} / \mathrm{L}$, respectively, indicating co-existence of aerobic ammonia oxidizers (AOB) and ANAMMOX. The free ammonia $\left(\mathrm{NH}_{3}\right)$ and free nitrous acid $\left(\mathrm{HNO}_{2}\right)$ concentrations were $26.61 \pm 16.54 \mathrm{mg} / \mathrm{L}$ and $(1.66 \pm 0.95) \times 10^{-5} \mathrm{mg} / \mathrm{L}$, preventing $\mathrm{NO}_{2}{ }^{-}-\mathrm{N}$ oxidation to $\mathrm{NO}_{3}{ }^{-} \mathrm{N}$ enabling sustained $\mathrm{NH}_{4}{ }^{+}-\mathrm{N}$ removal.
\end{abstract}

\section{KEYWORDS}

Anaerobic membrane bioreactor, Autotrophic bacteria, ANAMMOX, Landfill leachate, Ammonia removal 


\subsection{INTRODUCTION}

Ammonification and solubilization process releases the nitrogen from municipal solid waste (MSW) as $\mathrm{NH}_{4}{ }^{+}-\mathrm{N}$ in the leachate [1]. Partially treated landfill leachate from landfill bioreactor and old landfill leachate is an important source of wastewater rich in nitrogen load with low organic content. Typical $\mathrm{NH}_{4}{ }^{+}-\mathrm{N}$ in these leachates varies from $400-5100 \mathrm{mg} / \mathrm{L}$ [1, $2,3]$. As the landfill ages the methanogenic bacteria in the waste converts the volatile fatty acids (VFA) to $\mathrm{CH}_{4}$ and $\mathrm{CO}_{2}$. The organic material concentration is reduced as it ages, with the result that an older leachate has a relatively low but non-biodegradable organic fraction (100 to $3460 \mathrm{mg} / \mathrm{L}$ of COD) when compared to 13,000 to 50,000 mg/L of COD in the young landfill leachate $[1,2,4,5]$. The expected pathways of nitrogen transformations in a landfill condition include ammonification, sorption, volatilization, nitrification, heterotrophic denitrification, partial heterotrophic denitrification, autotrophic denitrification, anaerobic ammonium oxidation (ANAMMOX), and $\mathrm{NO}_{3}{ }^{-}-\mathrm{N}$ reduction. Discharge of strong nitrogenous leachates into the surface water can result in eutrophication, aquatic toxicity and emissions of nitrous oxide $\left(\mathrm{N}_{2} \mathrm{O}\right)$ to atmosphere [6]. $\mathrm{NH}_{4}{ }^{+}-\mathrm{N}$ accumulation in landfills poses long term pollution issue with significant interference during post closure [2] thereby requiring its removal $\left(\mathrm{NH}_{4}{ }^{+}-\mathrm{N}<50 \mathrm{mg} / \mathrm{L}\right.$ and $\left.\mathrm{NO}_{3}{ }^{-} \mathrm{N}<10 \mathrm{mg} / \mathrm{L}\right)$ prior to ultimate disposal into inland surface waters [7].

Traditional biological nitrogen removal of landfill leachate is achieved by autotrophic nitrification and then heterotrophic denitrification. Supplementation of organic carbon, such as methanol (3 $\mathrm{kg} \mathrm{CH} \mathrm{CH}_{3} \mathrm{OH} / \mathrm{kg} \mathrm{N}$ ) is required when organic carbon is insufficient [8]. Conventional biological nitrogen removal (BNR) is energy intensive $(2.8 \mathrm{kWh} / \mathrm{kg} \mathrm{N})$ require substantial space and results in high production of sludge (1 kg VSS/ kg N) [8,9]. Improved alternates in BNR such as ANAMMOX have achieved, partial autotrophic oxidation of $\mathrm{NH}_{4}{ }^{+}-$ $\mathrm{N}$ to $\mathrm{NO}_{2}{ }^{-}-\mathrm{N}$ along with denitrification based on $\mathrm{NO}_{2}^{-}-\mathrm{N}$ instead of $\mathrm{NO}_{3}{ }^{-}-\mathrm{N}$, yielding about $25 \%$ savings on energy and $40 \%$ savings on organic carbon addition costs $[9,10,11]$.

With $\mathrm{NH}_{4}{ }^{+}-\mathrm{N}$ as the preferred substrate for the ANAMMOX process, high $\mathrm{NH}_{4}{ }^{+}-\mathrm{N}$ concentration with low $\mathrm{NO}_{2}^{-}-\mathrm{N}$ and COD favor autotrophic ANAMMOX activity. ANAMMOX bacteria has not been obtained as a pure culture yet, but could be enriched as a dominant bacteria in a mixed culture comprising of aerobic ammonia oxidizing bacteria (AOB), nitrite oxidizing bacteria (NOB) and heterotrophs [9, 10]. Successful cultivation of slow growing ANAMMOX bacteria $\left(0.003 \mathrm{~h}^{-1} ; 0.072 / \mathrm{d}\right.$ at $\left.32^{0} \mathrm{C}\right)$ with complete biomass retention in high cell density systems by means of high reactor loading, low sludge production could be obtained in anaerobic membrane bioreactor (AnMBR) by producing ANAMMOX bacterial suspension as free cells or aggregates at high growth rate [12]. AnMBR is also suitable as a single stage nitritation/ANAMMOX process for treating strong nitrogenous wastewaters with low $\mathrm{COD}$ of $\mathrm{C} / \mathrm{N}$ ratio 0.5 to 2 [10]. When compared to conventional treatment technologies AnMBR exhibits higher $\mathrm{NH}_{4}{ }^{+}-\mathrm{N}$ removal performance $(>80 \% \mathrm{TKN})$ while treating landfill leachates at higher influent $\mathrm{NH}_{4}{ }^{+}-\mathrm{N}$ concentrations $(115-2280 \mathrm{mg} / \mathrm{L})$ [1,30-35]. 
Confirmation of ANAMMOX activity had been carried out by monitoring chemical nitrogen transformations [13] and/or by studying the microbial eco-physiology through molecular biology techniques [10]. This investigation describes the feasibility of applying ANAMMOX process for enhancing $\mathrm{NH}_{4}{ }^{+} \mathrm{N}$ removal treating nitrogen rich landfill leachate in AnMBR. The performance of AnMBR for treating landfill leachate by autotrophic ammonia removal is examined in this paper.

\subsection{MATERIALS AND METHODS}

\subsection{Experimental setup}

The schematic experimental setup is discussed in [14]. The AnMBR with a working volume of $15 \mathrm{~L}$ was filled with a mix of anaerobic seed $(60 \%)$ from biosolids digester and enrichment medium (40\%) as food, after excluding the $40 \%$ of headspace in total volume. The composition of the enrichment medium used was adopted from [9]. The feed tank containing enrichment medium was continuously stirred by an overhead stirrer at $100 \mathrm{rpm}$ to promote homogeneity of the influent, prevent the entrapment of nitrogen bubbles and to promote the process stability. The AnMBR effluent was continuously filtered by the membrane module driven by a permeation peristaltic pump (Watson Marlow 313) through the solenoid valve. This operation was controlled by cyclic timer, operating with a filtration cycle of $10 \mathrm{~min}$ and 2 min cut off. The water level sensor controlled the feed pump to maintain the reactor volume during the experimental period. Anoxic condition was maintained by suffocation method (i.e. cutting the oxygen supply) and the reactor was covered with black cloth to prevent phototrophic algal growth and $\mathrm{O}_{2}$ generation.

\subsection{Landfill leachate characteristics}

The leachate was collected regularly from a MSW dumpsite in Tamilnadu (India), brought to the laboratory and analyzed immediately. The characteristics of the leachate are presented in Table 1. The leachate was dark brown and fulvous in color with significant odor with the $\mathrm{pH}$ in the range of 7.53 to 7.87. The leachate high $\mathrm{C} / \mathrm{N}$ ratio (11) was diluted to reduce the COD and was spiked with $\mathrm{NH}_{4} \mathrm{Cl}$ to increase the influent $\mathrm{NH}_{4}{ }^{+}-\mathrm{N}$ concentration to 10,000 $\mathrm{mg} / \mathrm{L}$. The $\mathrm{C} / \mathrm{N}$ ratio used in the study was in the range of $(0.06$ to 0.12$)$ to favor ANAMMOX activity in AnMBR.

Table 1 Characteristics of leachate from the dumpsite

\begin{tabular}{llcccc}
\hline $\begin{array}{c}\text { Sl } \\
\text { No }\end{array}$ & Characteristics & Range & Mean & SD & $\begin{array}{c}\text { Characteristics of leachate fed to } \\
\text { AnMBR }\end{array}$ \\
\hline 1. & $\mathrm{pH}$ & $7.53-7.87$ & 7.7 & 0.17 & 7.0 \\
2. & $\mathrm{ORP}(\mathrm{mV})$ & -47 to -67 & -57 & 10 & - \\
3. & $\mathrm{NH}_{4}^{+}-\mathrm{N}$ & $834-850$ & 837.17 & 5.78 & 10,000 \\
4. & $\mathrm{NO}_{2}^{-}-\mathrm{N}$ & $1.81-2.02$ & 1.89 & 0.09 & $\mathrm{BDL}$ \\
5. & $\mathrm{NO}_{3}^{-}-\mathrm{N}$ & $5.28-49.20$ & 34.26 & 20.49 & $\mathrm{BDL}$ \\
\hline
\end{tabular}


Linnaeus ECO-TECH ' 14 ,

Kalmar, Sweden, November 24-26, 2014

\begin{tabular}{llcccc}
\hline 6. & COD & $7408-11760$ & 9530 & 1926 & 950 \\
7. & TKN & $746-1000$ & 890 & 79.81 & - \\
\hline
\end{tabular}

(All values except $\mathrm{pH}$ and $\mathrm{ORP}$ in $\mathrm{mg} / \mathrm{L}$ )

\subsection{Strategy of operation}

The ANAMMOX activity in AnMBR was initiated from anaerobic seed from biosolids digester (MLSS $50680 \mathrm{mg} / \mathrm{L}$; MLVSS $23450 \mathrm{mg} / \mathrm{L}$ ) and then operated for Nitrogen Loading Rate (NLR) varying from 0.025 to $5 \mathrm{~kg} \mathrm{NH}_{4}^{+}-\mathrm{N} / \mathrm{m}^{3} / \mathrm{d}$ at $2 \mathrm{~d}$ hydraulic retention time (HRT). The HRT was varied from 1 to $3 \mathrm{~d}$ with influent $\mathrm{NH}_{4}{ }^{+}-\mathrm{N}$ concentration of 10,000 $\mathrm{mg} / \mathrm{L}$ (3.33 to $10 \mathrm{~kg} \mathrm{NH}_{4}{ }^{+}-\mathrm{N} / \mathrm{m}^{3} / \mathrm{d}$ ) and optimized for $1.5 \mathrm{~d}$ HRT, as deliberated elsewhere [14].

Once the AnMBR was optimized for HRT, and NLR, the experiments with the landfill leachate was undertaken. Experiments with landfill leachate were conducted to evaluate the nitrogen removal performance of ANAMMOX process in AnMBR, at the optimum HRT of $1.5 \mathrm{~d}$ HRT with influent $\mathrm{NH}_{4}{ }^{+}-\mathrm{N}$ concentration of $10,000 \mathrm{mg} / \mathrm{L}$. During the course of experiment, the dissolved oxygen (DO) concentration in the AnMBR was in the range of 0.2 to $0.5 \mathrm{mg} / \mathrm{L}$. The $\mathrm{pH}$ of the AnMBR system was in the range of 7.53 to 7.87 , with an ORP range of -47 to $-67 \mathrm{mV}$. The performance of the AnMBR system at optimized condition using the landfill leachate was evaluated using effluent quality $\left(\mathrm{NH}_{4}{ }^{+}-\mathrm{N}, \mathrm{NO}_{3}{ }^{-}-\mathrm{N}, \mathrm{NO}_{2}{ }^{-}-\mathrm{N}\right.$, $\mathrm{N}_{2} \mathrm{H}_{4}$ and $\mathrm{NH}_{2} \mathrm{OH}$ ). Sampling of the influent, effluent and the MLSS of the AnMBR was performed every day, with about $100 \mathrm{~mL}$ sample was collected from the sampling/sludge port. The samples were prepared by filtering through $0.45 \mu$ filter paper (Whatman), prior to analysis. The nitrogen transformations were studied from the analyses of $\mathrm{NH}_{4}{ }^{+}-\mathrm{N}, \mathrm{NO}_{3}{ }^{-}-\mathrm{N}$, $\mathrm{NO}_{2}{ }^{-} \mathrm{N}$ [15] and ANAMMOX biomass development was determined from the metabolites, $\mathrm{N}_{2} \mathrm{H}_{4}$ and $\mathrm{NH}_{2} \mathrm{OH}[16,17]$ and indirectly by the MLVSS and MLSS estimations [15]. The concentration of free ammonia $\left(\mathrm{NH}_{3}\right)$ and free nitrous acid $\left(\mathrm{HNO}_{2}\right)$ were theoretically calculated according to Anthonisen et al. [18].

\subsection{RESULTS AND DISCUSSION}

\subsection{Nitrogen transformations in AnMBR treating landfill leachate}

With the optimized HRT of $1.5 \mathrm{~d}$, and NLR of $6.51 \pm 0.20 \mathrm{~kg} \mathrm{NH}_{4}{ }^{+}-\mathrm{N} / \mathrm{m}^{3} / \mathrm{d}$, treatment of the landfill leachate in AnMBR was evaluated. During the study with landfill leachate in AnMBR, there was the initial decrease in the nitrogen removal rates (NRR) as depicted in Figure 1 , in the leachate within $2 \mathrm{~d}$ (up to $3.15 \mathrm{~kg} \mathrm{NH}_{4}{ }^{-}-\mathrm{N} / \mathrm{m}^{3} / \mathrm{d}$ ) with removal efficiency as low as $49 \%$ on day 2 . The mean nitrogen removal efficiency during the $1^{\text {st }}$ week was $69 \%$. However from the $2^{\text {nd }}$ week onwards (day 8 to 33), nitrogen removal improved to $87 \%$. This is indicative of shock of ANAMMOX biomass when exposed to landfill leachate and eventual recovery of nitrogen removal efficiency. The approach of acclimating ANAMMOX biomass in AnMBR was by using simulated effluent [14] prior to the treatment of real effluent and was enabled by cell memory of ANAMMOX biomass [19]. A dip in NRR on day 33 was observed from 5.79 to $5.28 \mathrm{~kg} \mathrm{NH}_{4}{ }^{+}-\mathrm{N} / \mathrm{m}^{3} / \mathrm{d}$, and NRR was sustained at $5.93 \mathrm{~kg} \mathrm{NH}_{4}{ }^{+}-\mathrm{N} / \mathrm{m}^{3} / \mathrm{d}$ (average) till the end of the study. 
Overall the mean NRR of $5.54 \pm 0.63 \mathrm{~kg} \mathrm{NH}_{4}{ }^{+}-\mathrm{N} / \mathrm{m}^{3} / \mathrm{d}$ was obtained, with the average $\mathrm{NH}_{4}{ }^{+}$ $\mathrm{N}$ removal efficiency for treating landfill leachate was $85.13 \pm 9.67 \%$. $\mathrm{NH}_{4}{ }^{+} \mathrm{N}$ removal efficiency was achieved, possibly due to the cell memory of the biomass (not clear) that was exposed to the high nitrogen concentrations during simulated leachate experiments [14], attributable to the adaptation and recovery of the biomass to improve $\mathrm{NH}_{4}{ }^{+}-\mathrm{N}$ removal rate.

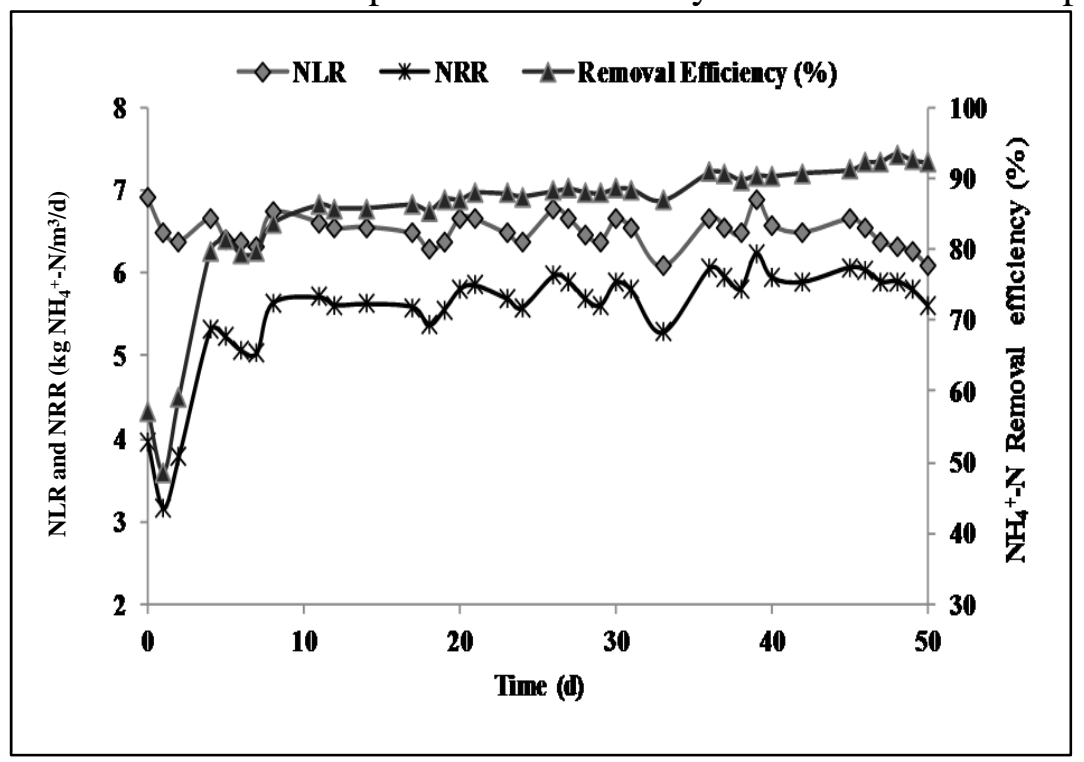

Figure 1 Nitrogen removal performance in AnMBR treating landfill leachate

The $\mathrm{NH}_{4}{ }^{+}-\mathrm{N}$ removal efficiency could also be affected by the presence of heavy metals, humic and fulvic acids, chlorinated organics and inorganic salts commonly found in landfill leachate [1]. The heavy metal concentrations of Fe - 1.28 to $76 \mathrm{mg} / \mathrm{L}, \mathrm{Mn}-0.02$ to $15.5 \mathrm{mg} / \mathrm{L}$, $\mathrm{Ba}-0.01$ to $0.15 \mathrm{mg} / \mathrm{L}, \mathrm{Cu}-0.005$ to $0.78 \mathrm{mg} / \mathrm{L}, \mathrm{Al}-0.02$ to $2.0 \mathrm{mg} / \mathrm{L}, \mathrm{Si}-3.72$ to 10.48 $\mathrm{mg} / \mathrm{L}$ has been reported [1] and suspected to affect the performance of AnMBR. The NRR during the simulated leachate experiments was $96 \%$ with NLR of $5 \mathrm{~kg} \mathrm{NH}_{4}{ }^{+}-\mathrm{N} / \mathrm{m}^{3} / \mathrm{d}$ at $2 \mathrm{~d}$ HRT [14]. In the effluent, $\mathrm{pH}$ was in the range of 7.51 to 8.10 while the COD was in the range of 15 to $45 \mathrm{mg} / \mathrm{L}$. The response of the ANAMMOX process to the change from simulated to actual leachate suggested that the gradual acclimation provided to the biomass was successful. Gradual adaptation of ANAMMOX biomass from fresh water to high salinity wastewater has already been reported by [20]. The incremental nitrogen removal rates of influent $\mathrm{NH}_{4}{ }^{+}-\mathrm{N}$ could be related to the increment of heterotrophic denitrifiers contribution with subsequent strengthening of the endogenous denitrification [20]. Hence, a pressure in environmental condition (increased NLR under anoxic environment) could force the system to reach a new equilibrium state (ANAMMOX process).

Since the biomass was already optimized for high $\mathrm{NH}_{4}{ }^{+}-\mathrm{N}$ concentration in the simulated leachate experiments, during the real leachate experiments $\mathrm{NH}_{4}{ }^{+}-\mathrm{N}$ concentration took a dip by day 2 with the effluent $\mathrm{NH}_{4}{ }^{+}-\mathrm{N}$ concentration of $5003 \mathrm{mg} / \mathrm{L}$, as depicted in Figure 2 (a). Likewise the $\mathrm{NO}_{2}^{-}-\mathrm{N}$ concentration went up to $140 \mathrm{mg} / \mathrm{L}$ on day 2 and then subsequently reduced to $126 \mathrm{mg} / \mathrm{L}$ by day 4, as shown in Figure 2 (b). But from day 5 the $\mathrm{NO}_{2}{ }^{-} \mathrm{N}$ 
concentrations increased up to as high as $245 \mathrm{mg} / \mathrm{L}$, which is considered toxic for ANAMMOX process $[19,21]$. The $\mathrm{NO}_{2}{ }^{-}-\mathrm{N}$ accumulation could be triggered by inhibition of ANAMMOX activity due to the interference of heavy metals, chlorinated organics and inorganic salts usually reported for landfill leachate [1]. Heavy metals are not easily biodegradable and can accumulate in organisms, causing biological accumulation toxicity. While there are few studies on the heavy-metal inhibition of ANAMMOX, in general about 1 mmol L ${ }^{-1} \mathrm{HgCl}_{2}$ fully inhibited ANAMMOX activity [22].

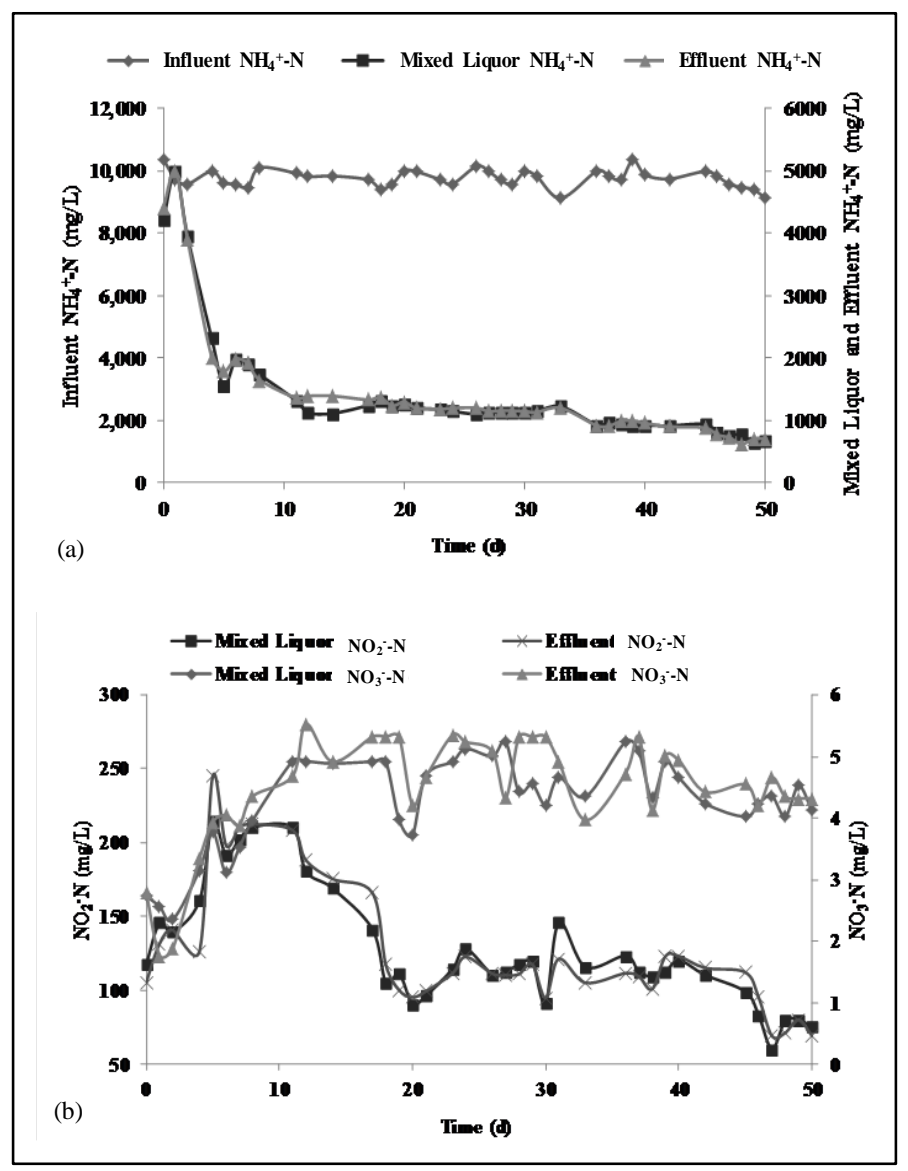

Figure 2 Nitrogen profile in AnMBR treating landfill leachate (a) $\mathrm{NH}_{4}{ }^{+}-\mathrm{N}$ transformations, (b) $\mathrm{NO}_{2}^{-}-\mathrm{N}$ and $\mathrm{NO}_{3}^{-}-\mathrm{N}$ changes

The $\mathrm{NH}_{4}{ }^{+}-\mathrm{N}$ removal due to ANAMMOX activity reduced from 81 to $79 \%$ from day 5 to 7 . But from day 8, the $\mathrm{NH}_{4}{ }^{+}-\mathrm{N}$ concentrations reduced steadily from $1646 \mathrm{mg} / \mathrm{L}$ to $1198 \mathrm{mg} / \mathrm{L}$ by day 33, which indicated improvement in the microbial community response from sudden shock to adaptation. From day 36 the concentrations of $\mathrm{NH}_{4}{ }^{+}-\mathrm{N}$ further reduced from 914 $\mathrm{mg} / \mathrm{L}$ to $620 \mathrm{mg} / \mathrm{L}$ on day 48 which was the lowest recorded $\mathrm{NH}_{4}{ }^{+}-\mathrm{N}$ concentration. The mean effluent $\mathrm{NH}_{4}{ }^{+}-\mathrm{N}$ concentrations at the end of the study was $1454.76 \pm 958.21 \mathrm{mg} / \mathrm{L}$, which was higher than $85.57 \pm 157.31 \mathrm{mg} / \mathrm{L}$ obtained during the simulated leachate study in AnMBR [14]. The presence of high effluent $\mathrm{NH}_{4}{ }^{+}-\mathrm{N}$ concentrations in the treated leachate 
could be due to interference of heavy metals typically found in the leachate affecting bacterial metabolism [11].

The mean $\mathrm{NO}_{2}{ }^{-} \mathrm{N}$ concentration of $127 \pm 40 \mathrm{mg} / \mathrm{L}$ was noticed while treating the landfill leachate in AnMBR. $\mathrm{NO}_{2}{ }^{-}-\mathrm{N}$ had proven to be a critical factor, reversibly inhibits the ANAMMOX activity, as reported in a SBR system at $\mathrm{NO}_{2}{ }^{-}-\mathrm{N}$ concentrations higher than 100 $\mathrm{mg} / \mathrm{L}$, and a complete loss of ANAMMOX activity at $185 \mathrm{mg} / \mathrm{L}$ of $\mathrm{NO}_{2}{ }^{-}-\mathrm{N}$ [23]. It was reported in another study that ANAMMOX activity had dropped by $50 \%$ when $\mathrm{NO}_{2}{ }^{-} \mathrm{N}$ concentrations were over $350 \mathrm{mg} / \mathrm{L}$ [21]. The average $\mathrm{NO}_{3}{ }^{-} \mathrm{N}$ concentration of $4.48 \pm 0.88$ $\mathrm{mg} / \mathrm{L}$ was obtained during the landfill leachate treatment in AnMBR, which was marginally higher than $3.34 \pm 0.98 \mathrm{mg} / \mathrm{L}$ of $\mathrm{NO}_{3}{ }^{-}-\mathrm{N}$ concentration during simulated leachate study [14], which also corresponded with results from other works [11].

\subsection{Molar ratio and ANAMMOX activity during landfill leachate treatment in AnMBR}

The stoichiometric ratio $\left(\mathrm{NH}_{4}{ }^{+}-\mathrm{N}\right.$ removed: $\mathrm{NO}_{2}{ }^{-}-\mathrm{N}$ converted: $\mathrm{NO}_{3}{ }^{-}-\mathrm{N}$ produced) indicating the ANAMMOX process of 1: 1.32: 0.26 [24] was verified during the landfill leachate study in AnMBR. The ratio acquired was 1: 0.10: 0.003 as indicated in the Figure 3 (a). This was lower than the ratio obtained during the simulated leachate study in AnMBR (1: 0.84: 0.02) [14]. In the experiments carried out by Dapena-Mora et al. [25] obtained ratios for $\mathrm{NO}_{2}{ }^{-} \mathrm{N}$ consumed/ $\mathrm{NH}_{4}{ }^{+} \mathrm{N}$ removed were 1.28 and 1.11 for Gas lift reactor and SBR reactor respectively, while Wyffels et al. [26] reported $\mathrm{NO}_{2}{ }^{-}-\mathrm{N} / \mathrm{NH}_{4}{ }^{+} \mathrm{N}$ ratio of 1.43. The ratio of $\mathrm{NO}_{2}{ }^{-} \mathrm{N}$ consumed/ $\mathrm{NH}_{4}{ }^{+}-\mathrm{N}$ removed is imperative to understand the ANAMMOX activity. From the $\mathrm{NO}_{2}{ }^{-} \mathrm{N}$ consumed/ $\mathrm{NH}_{4}{ }^{+}-\mathrm{N}$ removed ratio (0.10) it is evident that the ANAMMOX activity was reduced when exposed to the actual effluent, as anticipated. Yet besides the low $\mathrm{NO}_{2}{ }^{-}-\mathrm{N}$ conversion and $\mathrm{NO}_{3}{ }^{-}-\mathrm{N}$ production, the highest $\mathrm{NH}_{4}{ }^{+}-\mathrm{N}$ removal efficiency of $93.45 \%$ was achieved on the $48^{\text {th }}$ day of operation. For biomass having mixed populations of nitrifying and ANAMMOX bacteria, constant fine-tuning of feed $\mathrm{NO}_{2}{ }^{-}-\mathrm{N} / \mathrm{NH}_{4}{ }^{+}-\mathrm{N}$ ratio was needed in order to drive the process towards ANAMMOX activity which was represented by the ratio of the consumed $\mathrm{NO}_{2}{ }^{-}-\mathrm{N} / \mathrm{NH}_{4}{ }^{+}-\mathrm{N}$ [27].

The change in Specific ANAMMOX activity (SAA) is illustrated in the Figure 3 (b). The SAA obtained was $0.04 \pm 0.02 \mathrm{~kg} \mathrm{NH}_{4}{ }^{+} \mathrm{N} / \mathrm{kg}$ MLVSS/ d during the study with landfill leachate in AnMBR. The highest SAA of $0.0744 \mathrm{~kg} \mathrm{NH}_{4}{ }^{+}-\mathrm{N} / \mathrm{kg}$ MLVSS/ d was noticed on day 2. Furukawa et al.[13] has achieved SAA of $0.072 \mathrm{~kg} \mathrm{NH}_{4}{ }^{+}-\mathrm{N} / \mathrm{kg}$ MLVSS/ d while Wang et al.[10] reported $0.35 \mathrm{mg} \mathrm{NH}_{4}{ }^{+} \mathrm{N} / \mathrm{mg}$ MLVSS/ d. The type of effluent treated, kind of reactor configuration and operation mode play a significant role in the development and sustenance of SAA [27]. In this study, autotrophic $\mathrm{NH}_{4}{ }^{+}-\mathrm{N}$ removal of landfill leachate has been accomplished in AnMBR that has been previously operated with simulated leachate in order to develop ANAMMOX activity.

\subsection{Intermediates in AnMBR treating landfill leachate}

The changes in $\mathrm{NH}_{3}$ and $\mathrm{HNO}_{2}$ during the landfill leachate study are depicted in Figure 4 (a). The presence of $\mathrm{NH}_{3}$ and $\mathrm{HNO}_{2}$ affected NOB activity $[13,18]$ and prevented the $\mathrm{NO}_{2}{ }^{-}-\mathrm{N}$ oxidation to $\mathrm{NO}_{3}-\mathrm{N}[13,18]$. During the treatment of landfill leachate, the average theoretical 
concentrations of $\mathrm{NH}_{3}$ and $\mathrm{HNO}_{2}$ were $26.61 \pm 16.54 \mathrm{mg} / \mathrm{L}$ and $(1.66 \pm 0.95) \times 10^{-5} \mathrm{mg} / \mathrm{L}$. Anthonisen et al.[18] reported nitration inhibition by $\mathrm{NH}_{3}$ at 0.1 to $1.0 \mathrm{mg} \mathrm{NH}_{4}{ }^{+}-\mathrm{N} / \mathrm{L}$ and nitritation inhibition at $10-150 \mathrm{mg} \mathrm{NH}_{4}{ }^{+}-\mathrm{N} / \mathrm{L}$, resulted in $\mathrm{NO}_{2}^{-}-\mathrm{N}$ and $\mathrm{NH}_{4}{ }^{+}-\mathrm{N}$ accumulation. $\mathrm{NH}_{4}{ }^{+}-\mathrm{N}$ oxidation was considered to be less sensitive to $\mathrm{NH}_{3}$ inhibition than $\mathrm{NO}_{2}{ }^{-} \mathrm{N}$ oxidation [18]. But in partial nitritation process, half of the influent $\mathrm{NH}_{4}{ }^{+}-\mathrm{N}$ was converted to $\mathrm{NO}_{2}{ }^{-}-\mathrm{N}$ by AOB, with presence of the unionized forms of their substrate and product $\mathrm{NH}_{3}$ and $\mathrm{HNO}_{2}[9,18]$.

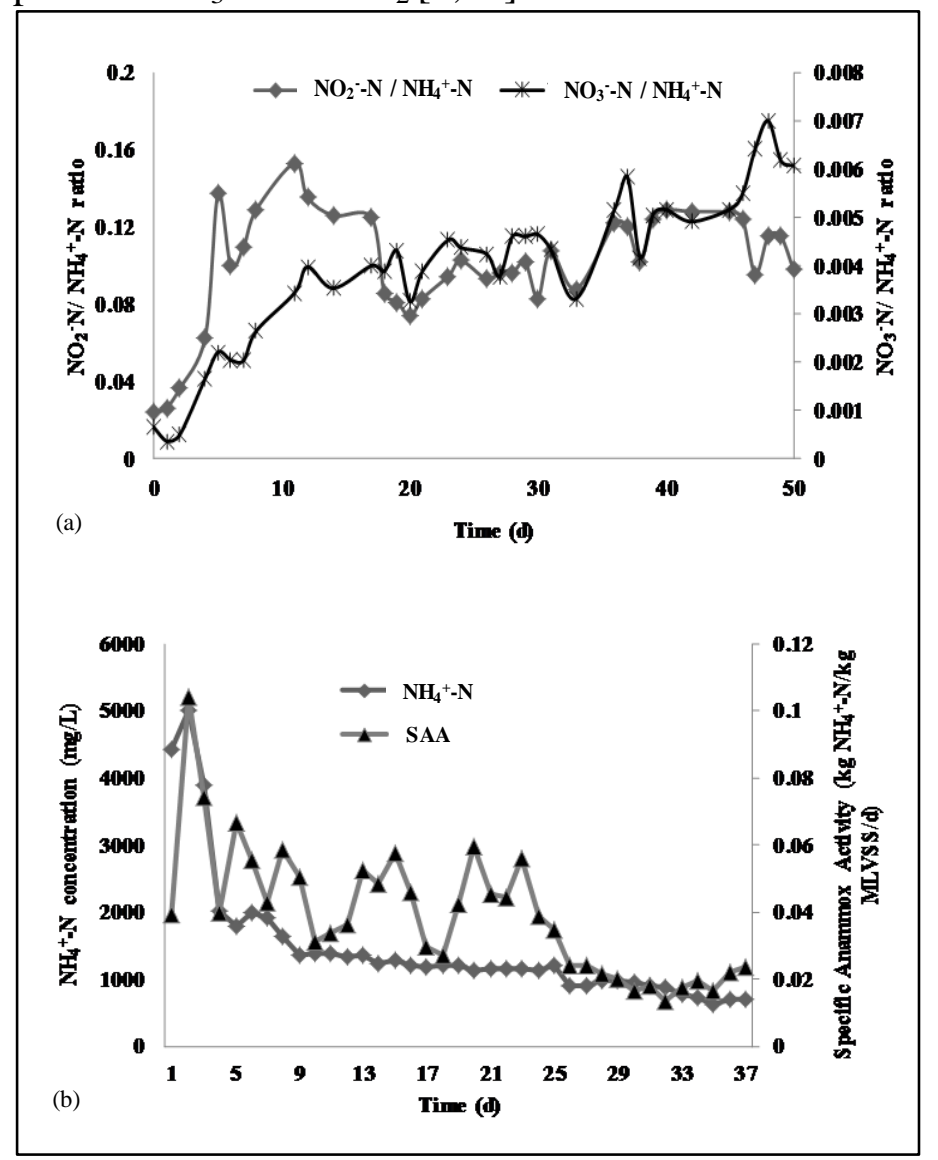

Figure 3 Molar ratio and ANAMMOX activity during landfill leachate treatment in AnMBR (a) $\mathrm{NO}_{2}{ }^{-} \mathrm{N}$ conversion and $\mathrm{NO}_{3}{ }^{-} \mathrm{N}$ production to the $\mathrm{NH}_{4}{ }^{+}-\mathrm{N}$ removed, (b) Specific ANAMMOX activity (SAA) in AnMBR

During the experimental period, $\mathrm{NH}_{4}{ }^{+} \mathrm{N}$ was present in excess in the reactor. Upon partial nitritation when part of the $\mathrm{NH}_{4}{ }^{+}-\mathrm{N}$ was oxidized to $\mathrm{NO}_{2}{ }^{-}-\mathrm{N}$ by AOB, occurrences of $\mathrm{NH}_{3}$ and $\mathrm{HNO}_{2}$ could have inhibited the NOBs. $\mathrm{HNO}_{2}$ can inhibit NOB more than AOB at concentrations of $\mathrm{HNO}_{2}$ between 0.22 to $2.8 \mathrm{mg} / \mathrm{L}$ [18]. At high $\mathrm{NH}_{3}$ concentrations, AOB compete over NOB leading to AOB enrichment in the system, as noticed in AnMBR [28]. $\mathrm{N}_{2} \mathrm{H}_{4}$ was reported to be continuously generated from $\mathrm{NH}_{4}{ }^{+}-\mathrm{N}$ and $\mathrm{NH}_{2} \mathrm{OH}$ through $\mathrm{NO}$ and eventually oxidized to $\mathrm{N}_{2}$ [12]. The electron acceptor for $\mathrm{N}_{2} \mathrm{H}_{4}$ oxidation could be $\mathrm{NH}_{2} \mathrm{OH}$ which was reduced to $\mathrm{NH}_{4}{ }^{+}$-N. If there was a drop in reduction rate of $\mathrm{NH}_{2} \mathrm{OH}$ it could lead 
to decrease in oxidation rate of $\mathrm{N}_{2} \mathrm{H}_{4}$, resulting in $\mathrm{N}_{2} \mathrm{H}_{4}$ accumulation. Maximum concentrations of $\mathrm{NH}_{2} \mathrm{OH}$ was attained on day 18 when the NLR was $6.28 \mathrm{~kg} \mathrm{NH}_{4}{ }^{+}-\mathrm{N} / \mathrm{m}^{3} / \mathrm{d}$ as depicted in Figure 4 (b). When the $\mathrm{N}_{2} \mathrm{H}_{4}$ concentration was as high as $0.014 \pm 0.01 \mathrm{mg} / \mathrm{L}$ on day 6, the effluent $\mathrm{NO}_{2}^{-}-\mathrm{N}$ concentration was the highest at $245 \mathrm{mg} / \mathrm{L}$. The mean $\mathrm{NH}_{2} \mathrm{OH}$ and $\mathrm{N}_{2} \mathrm{H}_{4}$ concentration were $0.006 \pm 0.001 \mathrm{mg} / \mathrm{L}(0.003$ to $0.009 \mathrm{mg} / \mathrm{L})$ and $0.008 \pm 0.005$ $\mathrm{mg} / \mathrm{L}(0.002$ to $0.019 \mathrm{mg} / \mathrm{L})$, indicative of AOB and ANAMMOX activity in AnMBR [12]. Jetten et al. [29] had reported that $\mathrm{N}_{2} \mathrm{H}_{4}$ could be generated upon addition of $\mathrm{NH}_{2} \mathrm{OH}$ or $\mathrm{NO}$ and regarded as a "benchmark" for ANAMMOX bacteria. In ANAMMOX enrichments of Candidatus 'Kuenenia stuttgartiensis' and Candidatus 'Brocadia fulgida' $\mathrm{NH}_{2} \mathrm{OH}$ was disproportionated into $\mathrm{NH}_{4}{ }^{+}-\mathrm{N}$ and $\mathrm{N}_{2}$ (3 mol NH $2 \mathrm{OH}$ into $1 \mathrm{~mol} \mathrm{~N}_{2}$ and $\left.1 \mathrm{~mol} \mathrm{NH}_{4}{ }^{+}-\mathrm{N}\right)$ [26].

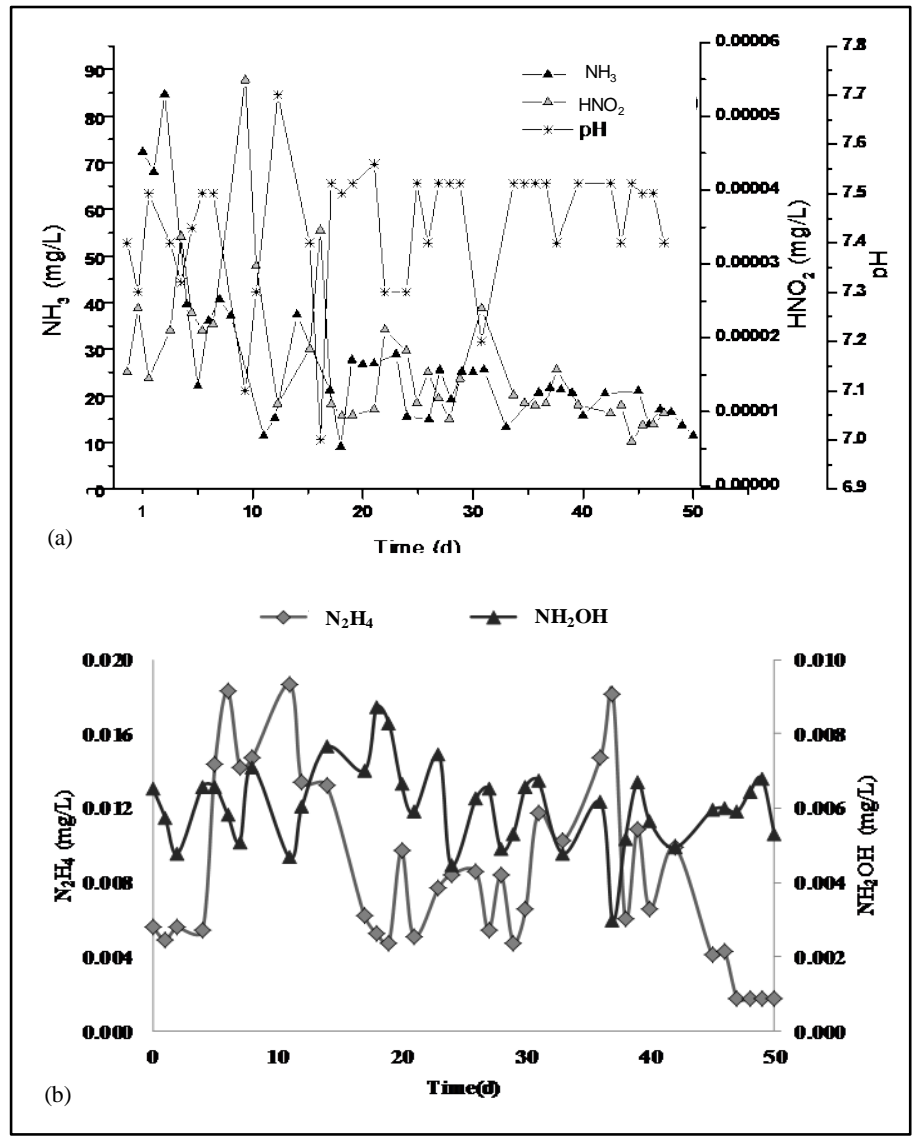

Figure 4 Changes in AnMBR treating landfill leachate (a) $\mathrm{NH}_{3}$ and $\mathrm{HNO}_{2}$ concentrations (b) $\mathrm{N}_{2} \mathrm{H}_{4}$ and $\mathrm{NH}_{2} \mathrm{OH}$ variation

\subsection{CONCLUSION}

Autotrophic ANAMMOX process in AnMBR was operated at NLR $6.51 \pm 0.20 \mathrm{~kg} \mathrm{NH}_{4}{ }^{+}-\mathrm{N} /$ $\mathrm{m}^{3} / \mathrm{d}$ at $1.5 \mathrm{~d}$ HRT and attained a $\mathrm{NH}_{4}{ }^{+}-\mathrm{N}$ removal efficacy of $85.13 \pm 9.67 \%$. Acclimation of ANAMMOX biomass from the anaerobic seed obtained from biosolids digester was feasible with nitrogen profile changes in $\mathrm{N}_{2} \mathrm{H}_{4}, \mathrm{NH}_{2} \mathrm{OH}, \mathrm{NH}_{3}$ and $\mathrm{HNO}_{2}$ concentrations, indicative of 
Linnaeus ECO-TECH ' 14 ,

Kalmar, Sweden, November 24-26, 2014

AOB and ANAMMOX activity with poor/low NOB activity enabling sustained autotrophic $\mathrm{NH}_{4}{ }^{+}-\mathrm{N}$ removal.

\subsection{ACKNOWLEDGEMENTS}

The Authors gratefully acknowledge the support given by the University Grants Commission Research Fellowship for meritorious scholars in Sciences to carry out this study.

\subsection{REFERENCES}

[1] Renou, S., Givaudan, J. G., Poulain, S., Dirassouyan, F., Moulin, P., 2008. Landfill leachate treatment: review and opportunity. Journal of Hazardous Materials. 150, 468 $-493$.

[2] Berge, N. D., Reinhart, D. R., Dietz, J., Townsend, T. G., 2006. In situ ammonia removal in bioreactor landfill leachate. Waste Management. 26, 334 - 343.

[3] Karthikeyan, O. P., Swati, M., Nagendran, R., Joseph, K., 2007. Performance of bioreactor landfill with waste mined from a dumpsite. Environmental Monitoring Assessment. 135(1-3), $141-151$.

[4] Lau, I. W. C., Wang, P., Fang, H. H. P., 2001. Organic removal of anaerobically treated leachate by Fenton coagulation. Journal of Environmental engineering and Science. 666 - 669 .

[5] Lo, I. 1996. Characteristics and treatment of leachates from domestic landfills. Environmental International. 22, 433 - 442.

[6] Philips, S., Laanbroek, H. J., Verstraete, W. 2002. Origin, causes and effects of increased nitrite concentrations in aquatic environments. Reviews in Environmental Science and Biotechnology. 1, 115 - 141.

[7] Ministry of Environment and Forests (MoEF), 2000. General Standards for Discharge of Environmental Pollutants, Available at http://hppcb.gov.in/eiasorang /spec.pdf (accessed on August 2012).

[8] Loosdrecht M. and Jetten, M. S. M. 1998. Microbiological conversions in nitrogen removal. Water Science and technology. 38(1), 1 - 7.

[9] Ganigue, R., Lopez, H., Ruscalleda, M., Balaguer, M. D., Colprim, J. 2008. Operational strategy for a partial nitritation-sequence batch reactor treating urban landfill leachate to achieve a stable influent for an ANAMMOX reactor. Journal for Chemical Technology and Biotechnology. 83, 365 - 371.

[10] Wang, T., Zhang, H., Yang, F., Liu, S., Fu, Z., Chen, H. 2009. Startup of the ANAMMOX process from the conventional activated sludge in a membrane bioreactor. Bioresource Technology. 100, 2501 - 2506.

[11] Fu, Z., Yang, F., An, Y., Xue, Y. 2009. Characteristics of nitrite and nitrate in situ denitrification in landfill bioreactors. Bioresource Technology. 100, 3015 - 3021.

[12] Star, R. L. W. V., Miclea, A. I., Dongen, U. G. J. M. V., Muyzer, G., Picioreanu, C., Loosdrecht, M. 2008. The Membrane Bioreactor: A novel tool to grow ANAMMOX bacteria as free cells. Biotechnology and Bioengineering. 101(2), 286 294. 
[13] Furukawa, K., Inatomi, Y., Qiao, S., Quan, L., Yamamoto, T., Isaka, K., Sumino, T. 2009. Innovative treatment system for digester liquor using ANAMMOX process. Bioresource Technology. 100, 5437- 5443.

[14] Suneethi, S. and Joseph, K. 2011. ANAMMOX process startup and stabilization with an anaerobic seed in Anaerobic Membrane Bioreactor (AnMBR). Bioresource Technology.102, 8860 - 8867.

[15] APHA/AWWA/WEF. American Public Health Association (APHA)/American Water Works Association (AWWA)/ Water Environment Federation (WEF). 1998. Standards Methods for the Examination of Water and Wastewater, $20^{\text {th }}$ ed. Washington, DC. United Book Press, USA.

[16] Watt G. W. and Chrisp, J. D. 1952. Spectrophotometric Method for Determination of Hydrazine. Analytical Chemistry. 24(12), 2006 - 2008.

[17] Frear D. S. and Burrell R. C. 1955. Spectrophotometric Method for Determining Hydroxylamine Reductase Activity in Higher Plants. Analytical Chemistry. 27(10), $1664-1665$.

[18] Anthonisen, A. C., Loehr, R. C., Prakasam, T. B. S., Srinath, E. G. 1976. Inhibition of nitrification by ammonia and nitrous acid. Journal (Water Pollution Control Federation). 48, 835 - 852.

[19] Egli, K., Fanger, U., Alvarez, P. J. J., Siegrist, H., Van der Meer, J. R., Zehnder, A. J. B. 2001. Enrichment and characterization of an Anammox bacterium from a rotating biological contactor treating ammonium-rich leachate. Archive of Microbiology. 175, 198 - 207.

[20] Kartal, B., Koleva, M., Arsov, R., Star, W. V. D., Jetten, M. S. M., Strous, M. 2006. Adaptation of a freshwater Anammox population to high salinity wastewater. Journal of Biotechnology. 126 (4), 546 - 553.

[21] Dapena-Mora, A., Fernandez, I., Campos, J. L., Mosquera-Corral, A., Mendez, R., Jetten, M. S. M. 2007. Evaluation of activity and inhibition effects on Anammox process by batch tests based on the nitrogen gas production. Enzyme and Microbial Technology. 40(4), $859-865$.

[22] Jetten, M. S. M., Strous, M., van de Pas-Schoonen, K. T., Schalk, J., van Dongen, U. G. J. M., van de Graaf, A. A., Logemann, S., Muyzer, G., van Loosdrecht, M. C. M., Kuenen, J. G. 1998. The anaerobic oxidation of ammonium, FEMS Microbiology Reviews. 22(5), 421 - 437.

[23] Bettazzi, E., Simone, C., Claudia, V., Claudio, L. 2010. Nitrite inhibition and intermediates effects on Anammox bacteria: A batch-scale experimental study. Process Biochemistry. 45(4), 573 - 580.

[24] Strous, M., Heijnen, J. J., Kuenen, J. G., Jetten, M. S. M. 1998. The sequencing batch reactor as a powerful tool for the study of slowly growing anaerobic ammonium-oxidizing microorganisms. Applied Microbiology and Biotechnology. 50, $598-596$.

[25] Dapena-Mora, A., Campos, J. L., Mosquera-Corral, A., Jetten, M. S. M., Mendez, R. 2004. Stability of the ANAMMOX process in a gas - lift reactor and a SBR. Journal of Biotechnology. 110, 159 - 170.

[26] Wyffels, S., Boeckx, P., Pynaert, K., Verstraete, W., Cllemput, V. O. 2003. Sustained nitrite accumulation in a membrane assisted bioreactor (MBR) for the 
treatment of ammonia rich wastewater. Journal of Chemical Technology and Biotechnology. 78(4), 412 - 419.

[27] Bagchi, S., Biswas, R., Nandy, T. 2010. Alkalinity and dissolved oxygen as controlling parameters for ammonia removal through partial nitritation and ANAMMOX in a single-stage bioreactor. Journal of Industrial Microbiology and Biotechnology. 37(8), $871-876$.

[28] Chen, J., Ji, Q., Zheng, P., Chen, T., Wang, C. 2010. Floatation and control of granular sludge in a high-rate Anammox reactor. Water Research. 44, 3321 - 3328.

[29] Jetten, M. S. M., Cirpus, I. E. Y., Kartal, B., van Niftrik, L. A. M. P., van de Pas-Schoonen, K., Sliekers, A. O., Haaijer, S., Star, W. R. L., van der Schmid, M. C., van de Vossenberg, J., Schmidt, I., Harhangi, H. R., van Loosdrecht, M. C. M., Kuenen, J. G., Op den Camp, H. J. M., Strous, M. 2005. 1994 - 2004: 10 years of research on the anaerobic oxidation of ammonium. Biochemical Society Transactions. 33, $119-123$.

[30] Tengrui, L., Harbawi, A. F. A., Bo, L. M., Jun, Z., Long, X. Y. 2007. Characteristics of Nitrogen removal from old Landfill Leachate by Sequence Batch Biofilm Reactor. American Journal of Applied Science. 4(4), 211 - 214.

[31] Bohdziewicz J. and Kwarciak, A. 2008. The application of hybrid system UASB reactor - RO in Landfill leachate treatment. Desalination. 222, 128 - 134.

[32] Bohdziewicz, J., Neczaj, E., Kwarciak, A. 2008. Landfill leachate treatment by means of anaerobic membrane bioreactor. Desalination. 221, 559 - 565.

[33] Giannis, A. Makripodis, G., Simantiraki, F., Somara, M., Gidarakos, E. 2008. Monitoring operational and leachate characteristics of an aerobic simulated landfill bioreactor. Waste Management. 28, 1346 - 1354.

[34] Jianguo, J., Guodong, Y., Zhou, D., Yunfeng, H., Zhonglin, H., Xiangming, F., Shengyong, Z., Chaoping, Z. 2007. Pilot - scale experiment on anaerobic bioreactor landfills in China. Waste Management. 27, 893 - 901.

[35] Liang, Z. and Liu, J. 2008. Landfill Leachate Treatment with a novel process: Anaerobic ammonium oxidation (Anammox) combined with soil infiltration system. Journal of Hazardous Materials. 151, 202 - 212. 